\title{
Effect of substitution of maize bran with chicken manure in semi-intensive pond culture of Tilapia rendalli (Boulenger)
}

\author{
Luness Mataka \& Jeremiah Kang'ombe \\ Department of Aquaculture and Fisheries Science, Bunda College of Agriculture, University of Malawi, Lilongwe, Malawi
}

Correspondence: Dr J Kang'ombe, Department of Aquaculture and Fisheries Science, Bunda College of Agriculture, University of Malawi, PO Box 219, Lilongwe, Malawi. E-mail: jeremiahkangombe@yahoo.com

\begin{abstract}
An experiment was carried out to determine the effect of substituting maize bran with chicken manure on the production of Tilapia rendalli semi-intensive pond culture. The experiment was carried out at Bunda College of Agriculture's fish farm, University of Malawi, where twelve $20 \mathrm{~m}^{2}$ concrete ponds of $1 \mathrm{~m}$ depth were used for 3 months from October 2005 to January 2006. A thin layer of soil was spread at the bottom of all ponds to allow growth of natural food. Each pond was stocked with 3 fish $\mathrm{m}^{-2}$ of $10.71 \mathrm{~g}$ average weight. Chicken manure was used as the organic manure applied at $1.6 \mathrm{~kg} 20 \mathrm{~m}^{-2}$ and substituted for maize bran by $25 \%$. All treatments were replicated three times. It was observed that fish growth was higher in the $3 / 4$ maize bran $+1 / 4$ chicken manure with a final weight of $25.1 \mathrm{~g}$, followed by $1 / 4$ maize bran $+3 / 4$ chicken manure with a final weight of $21.6 \mathrm{~g}$. The lowest final weight was $19.3 \mathrm{~g}$ in the chicken manure only, but did not differ significantly $(P<0.05)$ from the maize bran treatment, which had a final weight of $19.7 \mathrm{~g}$. This suggests that the use of chicken manure would produce better results and may increase yield when combined with supplementary feed like maize bran evidenced by high survival rates of $80 \%$ and above in all treatments.
\end{abstract}

Keywords: chicken manure, ponds, Tilapia rendalli, semi-intensive system, supplementary feed, small-scale farmers

\section{Introduction}

Pond culture is the most commonly used production system among small-scale farmers in developing countries. Compounded diets are unavailable and the farmers often use manures (animal excreta or compost) or inorganic fertilizers with inexpensive feed materials, e.g. maize bran (Wohlfarth \& Hulata 1987; Edwards 1990; Knud-Hansen 1998). Diets in aquaculture are mostly based on conventional feedstuffs such as fish oils and fishmeal (Goddard 1996), but these are expensive for the poor fish farmer. Attention is now being focused to the wiser use of the resources available on the farm. One major resource is the waste from agriculture of both animal and vegetable origins, either directly from the farm or as a by-product of processing plants.

There is an integrated fish farming system, which makes use of these wastes and by-products. Their use as fishpond inputs to enhance fish production is often the most efficient and versatile way to utilize them (Cowx 1982; ICLARM \& GTZ 1991). This system has proved to be particularly successful where resources are limited and maximum use needs to be made of wastes and other low-value agricultural products. Excretory wastes are also used as pond inputs to stimulate natural fish food or as supplementary feed. Semi-intensive pond systems seek to maximize the use of food production by using inorganic fertilizers, organic composts or manures and this are usually operated by small-scale farmers (Cowx 1982; Delince 1992; De Silva 1993).

The use of the wastes is a more suitable mechanism for the farmer to increase the productivity of the pond at minimal cost than the intensive feeding of fish. Wastes from poultry tend to have the highest concentrations of nitrogen $(\mathrm{N})$, phosphorus $(\mathrm{P})$ and potassium (K) compared with other sources of organic animal manures (Cowx 1982; Kang'ombe, Brown \& 
Halfyard 2006). The broiler/egg-laying chicken manure is commonly used because of the concentrated nutrient content. The semi-intensive production of tilapia in ponds using fertilizers and supplementary feed is a means to produce low-cost fish, which contributes to national food security in many developing countries including Malawi. Maize bran, which is the commonly used feed ingredient used by the smallholder farmers in Malawi, is sometimes scarce because there is greater competition between fish and other livestock as well as human beings during times of food shortages. This experiment was therefore carried out to evaluate the effect of substituting maize bran with chicken manure on the production of Tilapia rendalli in a semi-intensive concrete pond culture.

\section{Materials and methods}

\section{Pond preparation}

The experiment was carried out at Bunda College of Agriculture (BCA)'s fish farm using twelve $20 \mathrm{~m}^{2}$ concrete ponds $(5 \times 4 \mathrm{~m})$ of $1.1 \mathrm{~m}$ depth. These were prepared by laying soil (clay loam) of about $10 \mathrm{~cm}$ at the bottom to act as a substrate for the growth of natural food such as phytoplankton and zooplankton. It was conducted from November 2005 to January 2006. The experiment had four treatments with three replicates. The treatments were as follows: Treatment 1, maize bran only; Treatment 2,3/4 maize bran $+1 / 4$ chicken manure; Treatment $3,3 / 4$ chicken manure $+1 / 4$ maize bran; and Treatment 4 , chicken manure only on a wet basis. The treatments were assigned to ponds in a completely randomized design (CRD).

\section{Fish stocking and sampling}

Each concrete pond was stocked with juveniles of T. rendalli of mixed sex with an initial average weight of $10.71 \pm 0.12 \mathrm{~g}$ and an average total length of $87.1 \pm 1.5 \mathrm{~mm}$ each. The juveniles were obtained from Bunda College fish farm's breeding ponds. These were stocked at a density of 3 fish $\mathrm{m}^{-2}$ to make sure that uniform growth pattern was achieved and to limit intraspecific fighting of fish and competition over food (Likongwe 1983). This density was chosen in order not to limit any food availability in the ponds. This was based on previous studies in similar systems where fertilization and feeding are performed to replenish the available food and sustain the growth of fish for a certain culture period (Chikafumbwa et al. 1993). The fish were kept in a tank for 1 week as an acclimation period to make sure they were in good condition before stocking. A sample of 15 fish $(25 \%$ of stocked fish/pond) were weighed (g) and measured (total length in $\mathrm{mm}$ ) using an electric balance and a measuring board with a fixed ruler on it respectively. Repeated sampling was performed every 2 weeks using a seine net. The fish were anaesthetized using

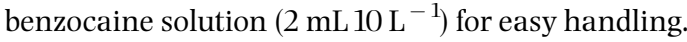
Fish were always returned to the ponds after each sampling.

\section{Pond fertilization and feeding}

The chicken manure was bought from Central Poultry Company based in Lilongwe city and the maize bran from the local mills around BCA. The manure was collected and transported to the fish farm while dry and kept in a dry tank in a shade. The ponds were fertilized with chicken manure 2 weeks before fish stocking. This was to make sure there was enough growth of natural food and other organisms. The manure and feed application rates were on weight basis where the substitution of maize bran by chicken manure was by weight (Bocek 2002). Application of chicken manure was performed once a week by broadcasting on top of the water at a rate of $1.6 \mathrm{~kg} 20 \mathrm{~m}^{-2}$. The rate of maize bran was based on the amount of manure applied by reducing the maize bran to increase the chicken manure. The maize bran was in the form of milled powder that was made into dough when feeding the fish. They were fed to satiation twice a day at 09:00 and 03:00 hours. The feed was not adjusted throughout the period because the substitution rate was constant and on a weight basis.

\section{Growth, survival and feed utilization}

The growth, survival and feed utilization were calculated according to Stickney (1994) as follows: specific growth rate $\left(\%\right.$ day $\left.^{-1}\right)=\left(\log _{\mathrm{e}}\right.$ final mean weight $(\mathrm{g})-\log _{\mathrm{e}}$ initial mean weight $\left.(\mathrm{g})\right) /$ time $\times 100$; total weight gain $=$ total final weight $(\mathrm{g})-$ total initial weight $(\mathrm{g})$; survival rate $(\%)=$ (initial number of fishnumber of dead fish)/initial number of fish $\times 100$; feed conversion ratios $(\mathrm{FCR})=$ dry weight of feed $(\mathrm{g}) /$ weight gain $(\mathrm{g})$; and feed conversion efficiencies $(\mathrm{FCE})=$ weight gain $(\mathrm{g}) /$ feed consumption $(\mathrm{g}) \times 100$. 


\section{Water quality monitoring}

The water quality data were collected as temperature, $\mathrm{pH}$, dissolved oxygen and turbidity. The instruments used were a thermometer, a multi-probe water checker (U-10 model, Horiba, Japan), the Winkler method and a Secchi disc. These were determined every day at 09:00 and 03:00 hours, except for turbidity, which was measured once a week. Temperature, $\mathrm{pH}$, dissolved oxygen and turbidity were measured because of the need to maintain high levels of water quality required to sustain rapid growth of healthy condition of cultured stock (Pillay 1994).

\section{Statistical analysis}

Analysis of the data was performed at a 5\% probability level using one-way analysis of variance (ANOVA). When significant differences were found among treatments, Duncan's multiple range test (DMRT) was used to test differences between treatment means. The analysis was performed using Statistical Package for Social Scientist (sPSs 11.0 Windows) (SPSS 1999).

\section{Results}

\section{Growth of fish}

The fish showed significant $(P<0.05)$ differences in the growth beginning from the sixth week (Fig. 1a and $b$ ). The initial weight of the fish did not differ significantly $(P>0.05)$ among treatments. Fish weights in the $3 / 4$ maize bran $+1 / 4$ chicken manure treatment were significantly $(P<0.05)$ higher than in the $1 / 4$ maize bran $+3 / 4$ chicken manure, chicken manure and maize bran treatments, which did not differ significantly $(P<0.05)$ from each other in the second sampling (Table 1). Fish weights in the maize bran and chicken manure were significantly $(P<0.05)$ lower than in the other treatments. The fish in ponds with $3 / 4$ maize bran $+1 / 4$ chicken manure and $1 / 4$ maize bran $+3 / 4$ chicken manure grew faster and differed significantly $(P<0.05)$ from the rest of the treatments throughout the experimental period.

The fish grew from an average weight of $10.7-25.3 \mathrm{~g}$ in the $3 / 4$ maize bran $+1 / 4$ chicken manure, $21.6 \mathrm{~g}$ in the $1 / 4$ maize bran $+3 / 4$ chicken manure, $19.7 \mathrm{~g}$ in maize bran and $19.30 \mathrm{~g}$ in chicken manure treatments. The growth curves also indicated that the fish increased significantly $(P<0.05)$ more in both weight and length in the $3 / 4$ maize bran $+1 / 4$ chicken manure treatment after 6 weeks in the experiment (Fig. 1a and $b)$.

The total weight gain of fish differed significantly $(P<0.05)$ among treatments. Fish in the $3 / 4$ maize bran $+1 / 4$ chicken manure treatment showed significantly $(P<0.05)$ higher weight gain $(14.34 \mathrm{~g})$, followed by those fish given $1 / 4$ maize bran $+3 / 4$ chicken manure (10.85 g), maize bran only (9.05 g) and chicken manure only (8.62 g). But maize bran and chicken manure did not differ significantly $(P<0.05)$ from each other (Table 1$)$.

\section{Survival of fish and feed utilization}

Survival rates ranged from $80 \%$ in the $3 / 4$ maize bran $+1 / 4$ chicken manure treatment to $96 \%$ in chicken manure only (Table 1). Fish-fed maize bran had a significantly $(P<0.05)$ higher FCR $(29.9)$ than the $3 / 4$ maize bran $+1 / 4$ chicken manure (14.2) and the $1 / 4$ maize bran $+3 / 4$ chicken manure (6.2).

\section{Water quality parameters}

Water quality parameters during the experimental period were within the required levels for the growth of $T$. rendalli in ponds. The mean $\mathrm{pH}$ ranged from 7.21 in maize bran treatment to 7.56 in the chicken manure treatment. The mean dissolved oxygen ranged from $16.19 \mathrm{mg} \mathrm{L}^{-1}$ in maize bran to $18.59 \mathrm{mg} \mathrm{L}^{-1}$ in the $1 / 4$ maize bran $+3 / 4$ chicken manure treatment. The minimum temperatures ranged from $20.0{ }^{\circ} \mathrm{C}$ in maize bran treatment to $22.5^{\circ} \mathrm{C}$ in the $3 / 4$ maize bran $+1 / 4$ chicken manure treatment, with the $1 / 4$ maize bran $+3 / 4$ chicken manure treatment having the maximum temperatures of $38.6{ }^{\circ} \mathrm{C}$ (Table 2).

The mean Secchi disc ranged from $26.57 \mathrm{~cm}$ in the $1 / 4$ maize bran $+3 / 4$ chicken manure treatment to $31.53 \mathrm{~cm}$ in the $3 / 4$ maize bran $+1 / 4$ chicken manure treatment (Table 2). The Secchi disc visibilities were significantly $(P<0.05)$ higher in maize bran and in the $3 / 4$ maize bran $+1 / 4$ chicken manure treatments but did not differ significantly $(P<0.05)$ between the $1 / 4$ maize bran $+3 / 4$ chicken manure and chicken manure treatments. Ammonia ranged from $0.16 \mathrm{mg} \mathrm{L}^{-1}$ in the maize bran treatment to $0.21 \mathrm{mg} \mathrm{L}^{-1}$ in the $1 / 4$ maize bran $+3 / 4$ chicken manure treatment. The differences in the physicochemical parameters of water between manured treatments and those substituted with chicken manure were not significantly $(P>0.05)$ different. 

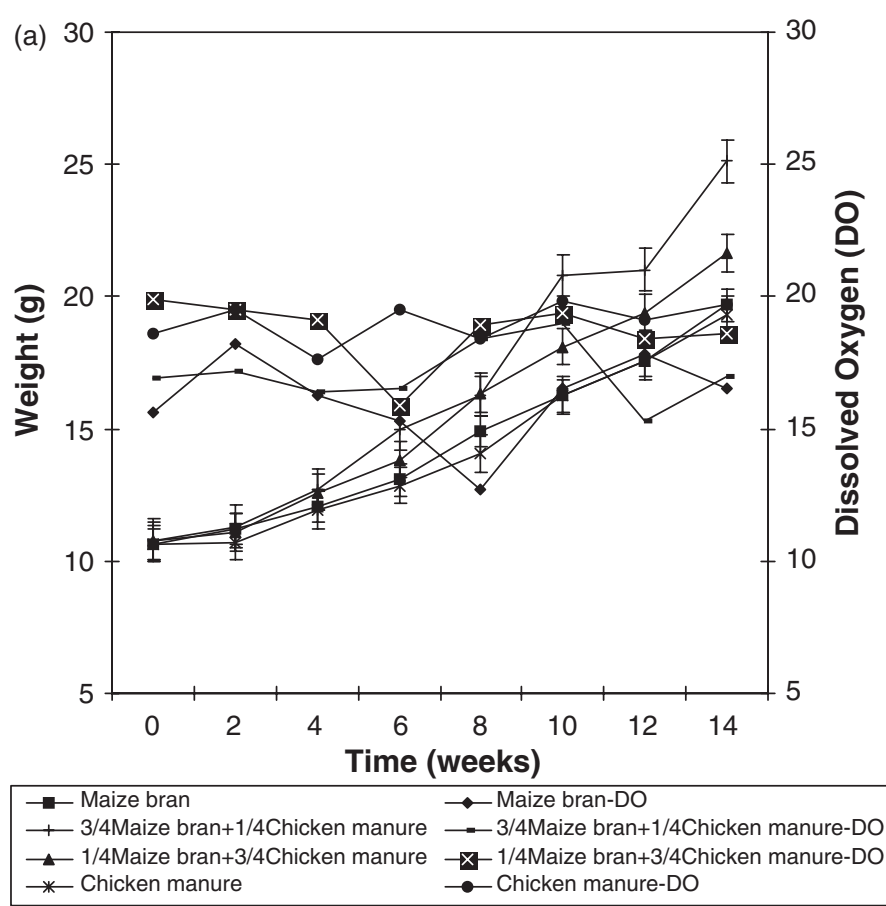

Figure 1 (a) Mean weight (g) of Tilapia

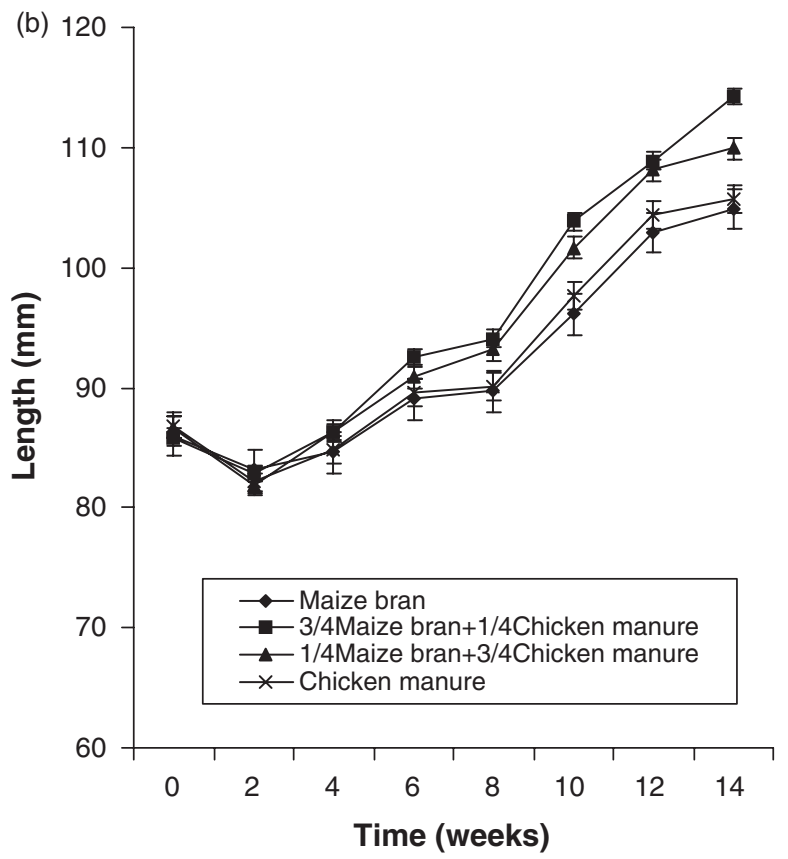
and dynamics of mean dissolved oxygen (DO) measured for the 14-week experimental period. (b) Mean length ( $\mathrm{mm}$ ) of Tilapia rendalli reared in different treatments for 14 weeks.

\section{Discussion}

The growth of $T$. rendalli revealed that the weight gain and specific growth rate were significantly higher in the $3 / 4$ maize bran $+1 / 4$ chicken manure treatment, followed by $1 / 4$ maize bran $+3 / 4$ chicken manure treatment. Higher growth of the fish in the manured and fed ponds may be due to the higher availability of natural food in these treatments (Shroeder 1983; Wohlfarth \& Hulata 1987). It is well known that tilapia in general feed on the undigested fraction of the manures directly, which is of low nutrient value but the micro-organisms adhering to them are of high protein value (Shroeder 1983). The 
Table 1 Initial weight, final weight, weight gain, weight gain per day, specific growth rate (SGR) and survival of Tilapia rendalli reared in ponds fertilized with chicken manure and fed with maize bran (means $\pm \mathrm{SE}$ )*

\begin{tabular}{|c|c|c|c|c|}
\hline \multirow[b]{2}{*}{ Parameter } & \multicolumn{4}{|l|}{ Treatment } \\
\hline & Maize bran & $\begin{array}{l}3 / 4 \text { maize bran }+ \\
1 / 4 \text { chicken manure }\end{array}$ & $\begin{array}{l}1 / 4 \text { maize bran }+ \\
3 / 4 \text { chicken manure }\end{array}$ & Chicken manure \\
\hline Initial weight (g) & $10.62 \pm 0.17$ & $10.78 \pm 0.19$ & $10.78 \pm 0.18$ & $10.66 \pm 0.20$ \\
\hline Final weight $(\mathrm{g})$ & $19.67 \pm 0.51^{a}$ & $25.12 \pm 0.74^{c}$ & $21.63 \pm 0.60^{b}$ & $19.28 \pm 0.58^{a}$ \\
\hline Weight gain (g) & $9.05 \pm 0.12^{\mathrm{a}}$ & $14.34 \pm 0.22^{c}$ & $10.85 \pm 0.15^{\mathrm{b}}$ & $8.62 \pm 0.12^{\mathrm{a}}$ \\
\hline SGR $\left(\%\right.$ day $\left.^{-1}\right)$ & $0.87 \pm 0.01^{a}$ & $1.18 \pm 0.01^{\mathrm{c}}$ & $0.97 \pm 0.01^{b}$ & $0.83 \pm 0.01^{a}$ \\
\hline $\mathrm{FCR} \dagger$ & $29.89 \pm 1.21^{\mathrm{C}}$ & $14.15 \pm 1.11^{\mathrm{b}}$ & $6.23 \pm 0.94^{a}$ & - \\
\hline FCE $(\%) \dagger$ & $3.0 \pm 0.1^{a}$ & $7.0 \pm 0.1^{b}$ & $16.0 \pm 0.3^{\mathrm{c}}$ & - \\
\hline Survival (\%) & $92.0 \pm 1.9^{c}$ & $80.0 \pm 1.3^{\mathrm{a}}$ & $89.0 \pm 1.6^{b}$ & $96.0 \pm 1.2^{c}$ \\
\hline
\end{tabular}

*Values with different superscripts in a row are significantly different (ANOVA, $P<0.05$ ).

$\dagger$ Calculated based on maize bran only.

FCE, feed conversion efficiencies; FCR, feed conversion ratios.

Table 2 Water quality parameters measured in ponds of Tilapia rendalli fertilized with chicken manure and fed with maize bran for 90 days (mean $\pm \mathrm{SE}$ )*

\begin{tabular}{|c|c|c|c|c|}
\hline \multirow[b]{2}{*}{ Parameter } & \multicolumn{4}{|l|}{ Treatment } \\
\hline & Maize bran & $\begin{array}{l}3 / 4 \text { maize bran }+ \\
1 / 4 \text { chicken manure }\end{array}$ & $\begin{array}{l}1 / 4 \text { maize bran }+ \\
3 / 4 \text { chicken manure }\end{array}$ & Chicken manure \\
\hline $\mathrm{pH}$ & $7.21 \pm 0.24$ & $7.47 \pm 0.10$ & $7.47 \pm 0.27$ & $7.56 \pm 0.06$ \\
\hline Oxygen ( $\mathrm{mg} \mathrm{L}^{-1}$ mean) & $16.19 \pm 0.85$ & $17.92 \pm 0.67$ & $18.59 \pm 1.03$ & $18.61 \pm 0.63$ \\
\hline Oxygen ( $\mathrm{mg} \mathrm{L}^{-1}$ range) & $0.4-21.52$ & $3.12-23.68$ & $2.1-23.68$ & $0.34-21.78$ \\
\hline Temp ( ${ }^{\circ} \mathrm{C}$ range) & $20.0-31.5$ & $22.50-32.0$ & $20.0-38.6$ & $22.40-32.0$ \\
\hline Secchi disc $(\mathrm{cm})$ & $31.39 \pm 1.23^{\mathrm{b}}$ & $31.53 \pm 1.22^{b}$ & $26.57 \pm 1.25^{\mathrm{a}}$ & $27.11 \pm 1.36^{\mathrm{a}}$ \\
\hline Ammonia (mg L $\left.{ }^{-1}\right)$ & $0.16 \pm 0.02$ & $0.19 \pm 0.48$ & $0.21 \pm 0.04$ & $0.17 \pm 0.02$ \\
\hline
\end{tabular}

*Values with different superscripts in a row are not significantly different (ANOVA, $P<0.05$ ).

biological productivity of any aquatic body is judged by the primary production, which forms the natural food of fish. Animal wastes like chicken manure lead to increased biological productivity of ponds through various pathways, which results in an increase in fish production (Nwachukwu 1997; Brummett 2000).

The specific growth rate for $T$. rendalli was $0.83 \%$ day $^{-1}$ in chicken manure and $1.18 \%$ day $^{-1}$ in the $3 / 4$ maize bran $+1 / 4$ chicken manure treatment in this experiment. These results are within the range of those reported from similar systems where the growth rate was $0.77 \%$ day $^{-1}$ in earthen ponds that were fertilized with chicken manure (Chikafumbwa et al. 1993; Kang'ombe 2004), although the application rates were slightly different. The results on primary production quantification also revealed that small particles of manure that are fine allow faster colonization by bacteria, algae, protozoans and quicker decomposition to enable the availability of food to the fish (Chikafumbwa, 1997). In this study, the survival rates were above $90 \%$ in ponds with chicken manure only, which was also consistent with the findings of Kang'ombe (2004).

Tilapia rendalli is a good candidate for aquaculture because it feeds low in the food chain and enrichment of water with fertilizers/manure increases plankton growth that in turn increases fish production. Msiska and Costa-Pierce (1999) indicated that the success of this culture is based on the understanding of existing food habitats in the fishponds and the extent to which these can be utilized for fish production. Limiting factors such as nutrients, light and space can be manipulated for optimum fish food production (Msiska \& Costa-Pierce 1999). Manure may become increasingly important because of increasing energy and chemical fertilizer costs and biologically it remains a feasible means of increasing fish yields. In this experiment, the application rates were deliberately designed to cover a wide range due to the varying rates worldwide (Msiska \& CostaPierce 1999; Garg \& Bhatnagar 2000). 
The FCR and FCE calculated based on maize bran were affected by treatments and were higher than expected in similar systems (Kang'ombe 2004). This is because the feed was not adjusted during the experimental period and might have been wasted as feed. However, it might have played a huge role as manure because the natural feed produced by the manure together with the maize bran improved the growth of fish in the treatment.

The water quality parameters play a significant role in the biology and physiology of fish including tilapia, which should be kept within range for their good performance (Boyd \& Tucker 1998; Martinez-Palacios, Tova, Taylor, Duran \& Ross 2002). Throughout the experiment, the water quality in all treatments remained within the favourable range required for tilapia (Boyd 1990; Pillay 1993). The water $\mathrm{pH}$, dissolved oxygen, turbidity, temperature and ammonia did not differ significantly between treatments. This suggests that chicken manure even at different doses did not have any adverse effect on the physico-chemical parameters of water. Even in the treatment of chicken manure only, it did not reduce the dissolved oxygen content of water. Similarly, Dhawan and Kaur (2002) reported that manures at a higher dosage did not have an adverse effect on the physico-chemical parameters in their pig dung experiment and showed higher growth rates of different fish species in ponds that were fertilized. However, there were low dissolved oxygen levels in the morning during this study. This phenomenon is common in fertilized ponds as there are low levels of dissolved oxygen early in the morning (Kangombe et al. 2006). This may be due to the high biological and chemical oxygen demand at night, which depletes the dissolved oxygen. The dissolved oxygen levels improve to levels that are above $2 \mathrm{mg} \mathrm{L}^{-1}$ as the sun rises and increase further towards mid morning. There were also elevated levels of maximum temperatures in the $1 / 4$ maize bran $+3 / 4$ chicken manure treatment despite the experimental ponds being situated in the same place. This is not strange during this period of the year (November-January) in Malawi when the temperatures are normally high (Internet Africa 1997). However, the mean temperatures were not significantly different among treatments.

The ammonia content of water in the current experiment did not differ significantly between different treatments. However, the ammonia $\left(\mathrm{NH}_{3}^{+}\right)$levels were higher in the $3 / 4$ maize bran $+1 / 4$ chicken manure treatment $\left(0.21 \mathrm{mg} \mathrm{L}^{-1}\right)$ than in maize bran only. This may be attributed to the combination of maize bran and chicken manure and because chicken manure contains higher phosphorus levels.

In conclusion, the results obtained in this experiment were based on a concrete pond culture environment. As a result, the rate of application of organic manure used may not be ideal and a similar experiment may be carried out in earthen ponds. Chicken manure contains phosphorus and nitrogen, which are the most limiting nutrients for the growth of algae. Above all, the substitution of poultry manures for maize bran is not only feasible but also cost effective and needs to be encouraged to utilize cheaper resources as maize bran may be scarce in other times of the year in Malawi. The study reveals that chicken manure can be utilized well when combined with a supplemental feed and when the manures are applied at recommended rates the water quality is not affected.

\section{Acknowledgments}

The authors would like to thank Icelandic International Development Agency (ICEIDA) for granting the funding for this research and Bunda College, University of Malawi for making the facilities available, Mr A. G. Matambo and Mr B. Lusangasi for the technical support rendered throughout the experimental period and lastly, Mr E. Nyali for lending a hand during laboratory work.

\section{References}

Bocek A. (2002) International centre for aquaculture and aquatic environments: water harvesting and aquaculture for rural development. Auburn University, AL, USA. Retrieved September 25, 2005 from http://www.ag.auburn. edu/fish/ icaae/organic.htm

Boyd C.E. (1990) Water Quality for Pond Culture. Alabama Agricultural Experimental Station, Auburn University, Auburn, AL, USA, 482pp.

Boyd C.E. \& Turcker C.S. (1998) Pond Aquaculture Water quality Management. Kluwer Academic Publishers, Boston, MA, USA, 700pp.

Brummett R.E. (2000) Food organism availability and resource partitioning in organically or inorganically fertilized Tilapia rendalli ponds. Aquaculture 183, 57-71.

Chikafumbwa J.K.T., Costa-Pierce B.A., Jamu D.M., Kadongola W.K. \& Balarin J.D. (1993) Investigations on the use of on-farm resources as pond inputs to culture Tilapia rendalli and Oreochromis shiranus on smallholder farms in rural Malawi. Aquaculture 117, 261-271. 
Cowx I.G. (1982) Aquaculture Development in Africa, Vol. 1, Manual for Aquaculture Extensionists, TP/AQUA/5. Commonwealth Secretariat, London, UK.

Delince G. (1992) The Ecology of the Fishpond. Kluwer Academic Publishers, Dordrecht, the Netherlands.

De Silva S.S. (1993) Supplementary feeding in semi-intensive aquaculture systems. In: Farm Made Aquafeeds. Proceedings of the FAO/AADCP Regional Expert Consultation on Farm-Made Aquafeeds, Bangkok, Thailand, 14-18 December 1992, (ed. by M.B. New, A.G.J. Tacon \& I. Csavas), pp 24-60. FAO-RAPA/AADCP, Bangkok, Thailand.

Dhawan A. \& Kaur S. (2002) Pig dung as pond manure: effect on water quality, pond productivity and growth of carps in polyculture system. In: Aquabyte-Aquaculture Section of the Network of Tropical Aquaculture and Fisheries Professionals. Naga, The ICLARM Quarterly, Vol. 25, No.1, (ed. by M.V. Gupta), pp. 11-14. International Center for Living Aquatic Resources Management, Manila, Philippines.

Edwards P. (1990) An alternative excreta-reuse strategy for aquaculture: the production of high-protein animal feed. In: Wastewater-fed aquaculture. Proceedings of the International Seminar on Wastewater Reclamation and Reuse for Aquaculture, (ed. by P. Edwards \& R.S.V. Pullin), pp. 209221. Environmental Sanitation Information Center, Asian Institute of Technology, Bangkok, Thailand.

Garg S.K. \& Bhatnagar A. (2000) Effect of fertilization frequency on pond productivity and fish biomass in still water ponds stocked with Cirrhinus mrigala (Ham.). Aquaculture Research 31, 409-414.

Goddard S. (1996) Feed Management in Intensive Aquaculture. Fisheries and Marine Institute, Memorial University, Chapman \& Hall, London, UK.

ICLARM \& GTZ. (1991) The context of small-scale integrated agriculture systems in Africa: a case study of Malawi, ICLARM stud., Rev.18, 302pp. International Center for Living Aquatic Resources Management, Manila, Philippines, and Deutsche Gesellschaft für Techische Zusammenarbeit, GmbH Frankfurt, Germany.

Internet Africa (1997) Malawi climate. Retrieved 10 August 2006 from http://www.africanet.com/africanet/country/ malawi/climate.htm

Kang'ombe J. (2004) Development of feeding protocols for Tilapia rendalli in Malawi reared in semi-intensive systems. $\mathrm{PhD}$ thesis, Memorial University of Newfoundland, Canada, 221pp.

Kang'ombe J., Brown J.A. \& Halfyard L.C. (2006) Effect of using different types of organic animal manure on plank- ton abundance, and on growth and survival of Tilapia rendalli (Boulenger) in ponds. Aquaculture Research 37, 1360-1371.

Knud-Hansen C.F. (1998) Pond Fertilization: Ecological Approach and Practical Application. Pond Dynamics/Aquaculture Collaborative Research Support Program Oregon State University, Corvallis, OR, USA, 125pp.

Likongwe J.S. (1983) The effect of supplementary feeding and fertilization on growth and yield of Sarotheradon shiranus chilwae in ponds. BSc Project, University of Malawi, Bunda College of Agriculture, Lilongwe, Malawi.

Martinez-Palacios C.A., Tova E.B., Taylor J.F., Duran G.R. \& Ross L.G. (2002) Effect of temperature on growth and survival of Chirostoma estor estor, Jordan 1879, monitored using simple video technique for remote measurement of length and mass of larval and juvenile fishes. Aquaculture 209, 369-377.

Msiska O.V. \& Costa-Pierce B.A. (1999) Maturity and gonad changes of Oreochromis (Nysalapia) karongae raised in fish ponds in Malawi. Journal of Applied Ichthiology $\mathbf{1 5}$, 97-103.

Nwachukwu V.N. (1997) Tilapia nutrition through substrate enhancement in ponds: a cheap, sustainable, and environmentally friendly feeding method. In: Proceedings from the Fourth International Symposium on Tilapia in Aquaculture, Vol. I Coronado Springs Resort Walt Disney World, Orlando, FL, USA, 9-12 November 1997, (ed. by K. Fitzsimmons), pp. 50-57. NRAES, Orlando, FL, USA.

Pillay T.V.R. (1993) Aquaculture Principles and Practices. University Press, Cambridge, UK.

Pillay T.V.R. (1994) Aquaculture Development Progress and Prospects. Fishing News Books, London.

Shroeder G.L. (1983) The role of natural feeds in Tilapia growth: a study based on stable isotope analyses. In: International Symposium onTilapia in Aquaculture, Nazareth, Israel, 8-13 May 1983, (ed. by L. Fishelson \& Z. Yaron), pp. 313-322. ICLARM, Manila, Philippines.

SPSS. (1999) SPSS Base 11.O for Windows. SPSS, Chicago, IL, USA.

Stickney R.R. (1994) Principles of Aquaculture. University of Washington, John Wiley and Sons, New York, NY, USA.

Wohlfarth G.W. \& Hulata G. (1987) Use of manure in Aquaculture. In: Detritus and Microbial Ecology in Aquaculture. ICLARM Conference Proceedings 14, Bellagio. Commo, Italy (ed. by D.J. Moriatry \& R.S.V. Pullin), pp. 353-367. International Center for Living Aquatic Resources Management, Manila, Philippines. 